\title{
Measuring Technical Efficiency and Returns to Scale in Indian Agriculture Using Panel Data: A Case Study of West Bengal
}

\author{
Debasis Mithiya $^{1}$, Simanti Bandyopadhyay ${ }^{2}$, Kumarjit Mandal ${ }^{3}$ \\ ${ }^{1}$ Guest Professor of Economics, Department of Business Administration, International School of Hospitality \\ Management, Kolkata, India \\ ${ }^{2}$ Associate Professor of Economics, Department of Economics, Victoria Institution (College), University of Calcutta, \\ Kolkata, India \\ ${ }^{3}$ Associate Professor of Economics, Department of Economics, University of Calcutta, Kolkata, India
}

Correspondence: Debasis Mithiya, Guest Professor of Economics, Department of Business Administration, International School of Hospitality Management, Kolkata, India.

Received: June 20, 2019

doi:10.11114/aef.v6i6.4332
Accepted: August 13, $2019 \quad$ Available online: September 24, 2019

URL: https://doi.org/10.11114/aef.v6i6.4332

\begin{abstract}
The study investigates farm level technical efficiency (TE) and its determinants in the state of West Bengal in India. A stochastic production frontier model has been applied for determining technical efficiency by using panel data on 17 agricultural production units over a period of 23 years. Maximum-likelihood estimates of the Cobb-Douglas stochastic frontier production function in a time-variant truncated normal distribution is appropriate for the measurement of technical efficiency of West Bengal agriculture in India. The estimated variance ratio indicates that 48.90 percent of the differences between the observed and the estimated output is caused by differences in farms' technical inefficiencies. However, the remaining variation is due to factors beyond farmers' control. The study shows that the agricultural farms in West Bengal exhibit increasing returns to scale in production. The study finds that farmers' education and agricultural extension are important determinants of technical efficiency. Other prominent determinants that have a significant contribution are farm size, crop diversification, number of available agricultural markets, the proportion of small landholders and input intensity. All these determinants, excluding the proportion of small landholders, have a largely positive impact on technical efficiency. The maximum-likelihood estimation (MLE) and principal component analysis (PCA) are applied to determine the effects of determinants on TE. Both methods give similar results.
\end{abstract}

Keywords: agricultural extension, cobb-douglas, crop diversification, maximum likelihood estimation, panel data, principal component analysis, stochastic frontier, technical efficiency, time-variant, truncated normal distribution

\section{JEL Classification: C23, Q12}

\section{Introduction}

West Bengal is an important state in the eastern part of India in terms of agricultural production. It is predominantly an agrarian state covering 2.7 percent of India's geographical area while supporting nearly 8 percent of the country's population (India Population, 2017). During 2014-2015, West Bengal had a gross cropped area of 9.6 million hectares and contributed around 19 percent to the gross state domestic product (GSDP). This led the state to contribute 9.73 percent to national production while covering 4.88 percent of net agrarian area. Agriculture still remains the most important means of livelihood of the rural masses in West Bengal. There are 7.12 million agricultural families 96 percent of whom are small and marginal farmers. The average size of land holding is less than one hectare. However, the state has diverse natural resources and varied agro-climatic conditions which support the cultivation of a wide range of crops. In terms of producing paddy and vegetables West Bengal ranks first and is the second largest producer of potato. It is also the leading producer of jute, pineapple, litchi, mango, and loose flowers (https://wb.gov.in/portal/web/guest/agriculture). The cultivation of pulses, oilseeds, and maize are also picking up fast. Though the structure of agriculture in West Bengal in the post-liberalization era has undergone a change (Mithiya, et.al., 2018), a huge gap still exists between the demand and the production of pulses, oilseeds, maize, and other agricultural commodities. A study on technical efficiency of agricultural production in West Bengal is therefore, quite necessary to understand it's contribution in bridging this gap. 
In this study, an attempt has been made to measure the Technical Efficiency (TE) of agricultural production in various farms of West Bengal during the post-liberalization period. Here, for the sake of analysis, each district of the states has been considered as a unit of production. Hence, each district has been identified with a farm. The study also attempts to point out the various factors determining the TE levels of different farms. Such information can be useful to identify the farms (districts) with low efficiency and suggest measures to improve the same. The study takes into account crop diversification, farmers' education and agricultural extension as major determinants of TE in addition to size of land holding, proportion of small landholders, number of available agricultural markets and input-intensity.

Technically, a production function is efficient if a farm produces the maximum quantity of output attainable with given inputs. Thus, the production frontier is the locus of the technically efficient input-output combinations. Inefficiency arises once a farm produces an amount of output that is within the production frontier. In other words, TE refers to the ability to minimize input use in the production of a given output vector or the ability to obtain maximum output from a given input vector. Therefore, a producer is technically efficient if an increase in an output leads to a reduction in at least one other output or an increase in at least one input, and if a reduction in any input causes an increase in at least one other input or a reduction in at least one output (Koopmans, 1951).

Technical efficiency is measured by both non-parametric and parametric methods. Non-parametric methods include Data Envelopment Analysis (DEA) or Free Disposal Hull (FDH). These methods originate from operation research and use linear programming to calculate an efficient deterministic frontier against which units are compared. The parametric methods including Stochastic Frontier Analysis (SFA), Thick Frontier Approach (TFA), and Distribution-Free Approach (DFA) utilize econometric estimation. The econometric theory is used to estimate pre-specified functional form and inefficiency is modeled as an additional stochastic term (Furková, 2011). Therefore, TE can be modeled using either the deterministic or the stochastic production frontier. In the case of the deterministic frontier model, the entire shortfall of observed output from the maximum feasible output is attributed to technical inefficiency, whereas the stochastic frontier model includes the eff ect of random shocks to the production frontier. SFA has been chosen over DEA in the present study to measure TE as it can separate random noise from efficiency which DEA cannot. DEA does not specify the nature of the production function and also not considers random noise. Therefore, the efficiency estimates may be biased in DEA.

The quantification of TE for a production unit (farm) has been extensively researched by agricultural economists over the years. The assessment of farm level technical efficiency and the factors influencing it, provide useful information to improve economic performance of farms. The efficient uses of available resources is important for economic viability and sustainability of agricultural farms in the long run. Therefore the measurement of technical efficiency is important for analyzing the overall economic performance of farms (Ahmadzai, 2004). The identification of determinants of technical efficiency is of significant importance for facilitating agricultural growth using productive agricultural strategy. This in turn is of utmost importance to farmers to ascertain their individual productivity and to reduce costs.

\section{Objective}

The primary objective of this study is to estimate the level of TE and identify the factors that determine it. The specific objectives are as follows:

a) To estimate the levels of Technical Efficiency of different farms (district as a unit) in West Bengal during post-liberalization era

b) To estimate whether the agricultural farms in West Bengal exhibit economies of scale,

c) To see how farm size, crop diversification, farmers' education and agricultural extension are influencing Technical Efficiency,

\section{Method and Materials}

\subsection{Data}

A panel data on 17 production units (districts) for the period of 23 years (1991-92 to 2013-2104), have been used. Secondary data relating to agricultural production, area, irrigation, fertilizer consumption, rural literacy rate and the number of agricultural markets at the district level in West Bengal have been collected from various issues of District Statistical Hand Book (Govt. of West Bengal, 1990-91 to 2013-14). The district level statistics on agricultural labor, average size of holding, number of small farmers have been taken from Estimates of Area \& Production of Principal crops in West Bengal (Govt. of West Bengal, 1990-91 to 2013-14). Since disaggregated data for the districts of North and South Dinajpur are not available during the period from 1991-92 to 1995-96, the two districts have been taken as a single unit in the name of West Dinajpur.

The estimates of crop diversification have been calculated by the authors on the basis of available data on cultivated 
area. The authors have also calculated the labor, fertilizer and irrigation intensity from available statistics.

\subsection{Theoretical Model}

TE in an agricultural farm is measured as the ratio between the observed output and the stochastic frontier output (potential output) under the assumption of fixed input (or, alternatively, as the ratio between the observed input and the minimum input under the assumption of fixed output). The stochastic frontier output is the potential output possible given the available technology and inputs used. In stochastic frontier, all deviations from potential output are attributed to inefficiency. However, sometimes potential output might itself fall due to exogenous shocks. As a results the production frontier might shift downwards. The stochastic frontier output is given by

$$
\mathrm{Y}_{\mathrm{i}}^{*}=f\left(\mathrm{X}_{\mathrm{i}} ; \beta_{\mathrm{i}}\right) \cdot \exp \left(\mathrm{v}_{\mathrm{i}}\right)
$$

The actual output is given by

$$
\mathrm{Y}=f\left(\mathrm{X}_{\mathrm{i}} ; \beta_{\mathrm{i}}\right) \cdot \exp \left(\mathrm{v}_{\mathrm{i}}\right) \cdot \exp \left(-\mathrm{u}_{\mathrm{i}}\right) ; \quad \mathrm{v}_{\mathrm{i}} \leq 0 \quad \text { and } \quad \mathrm{u}_{\mathrm{i}} \geq 0
$$

$f\left(\mathrm{X}_{\mathrm{i}} ; \beta_{\mathrm{i}}\right), \quad \exp \left(\mathrm{v}_{\mathrm{i}}\right), \quad \exp \left(-\mathrm{u}_{\mathrm{i}}\right)$ and $f(\mathrm{X} ; \beta) \cdot \exp (\mathrm{v})$ are a deterministic kernel, an effect of exogenous shocks on output, inefficiency and stochastic frontier respectively.

By definition,

$$
\begin{gathered}
\mathrm{TE}=\mathrm{Y}_{\mathrm{i}} / \mathrm{Y}_{\mathrm{i}}^{*} \quad 0 \leq \mathrm{TE} \leq 1 \\
=f\left(\mathrm{X}_{\mathrm{i}} ; \beta_{\mathrm{i}}\right) \cdot \exp \left(\mathrm{v}_{\mathrm{i}}\right) \cdot \exp \left(-\mathrm{u}_{\mathrm{i}}\right) / f\left(\mathrm{X}_{\mathrm{i}} ; \beta_{\mathrm{i}}\right) \cdot \exp \left(\mathrm{v}_{\mathrm{i}}\right) \\
=\exp \left(-\mathrm{u}_{\mathrm{i}}\right) ; \mathrm{u}_{\mathrm{i}} \geq 0 \\
=\mathrm{e}_{\mathrm{i}}^{-\mathrm{u}}
\end{gathered}
$$

Therefore,

$$
\begin{aligned}
\mathrm{Y}_{\mathrm{i}}=\mathrm{Y}_{\mathrm{i}}^{*} \cdot \mathrm{TE} & =f\left(\mathrm{X}_{\mathrm{i}} ; \beta_{\mathrm{i}}\right) \cdot \exp \left(\mathrm{v}_{\mathrm{i}}\right) \cdot \mathrm{TE} \\
& =f\left(\mathrm{X}_{\mathrm{i}} ; \beta_{\mathrm{i}}\right) \cdot \exp \left(\mathrm{v}_{\mathrm{i}}-\mathrm{u}_{\mathrm{i}}\right) ;
\end{aligned}
$$

$$
\left(v_{i}-u_{i}\right) \text { is the composite error term }
$$

Where, the $u_{i}$ is the inefficiency term and it always lies between 0 and 1 . When $u_{i}$ is equal to zero, TE $=1$, then production is on the frontier. Therefore a farmer is technically efficient. When $u_{i}$ is greater than zero $\left(u_{i}>0\right)$ the farmer is technically inefficient (TE $<1$ ), since production will be inside the frontier. Diagrammatically it is given in Figure 1.

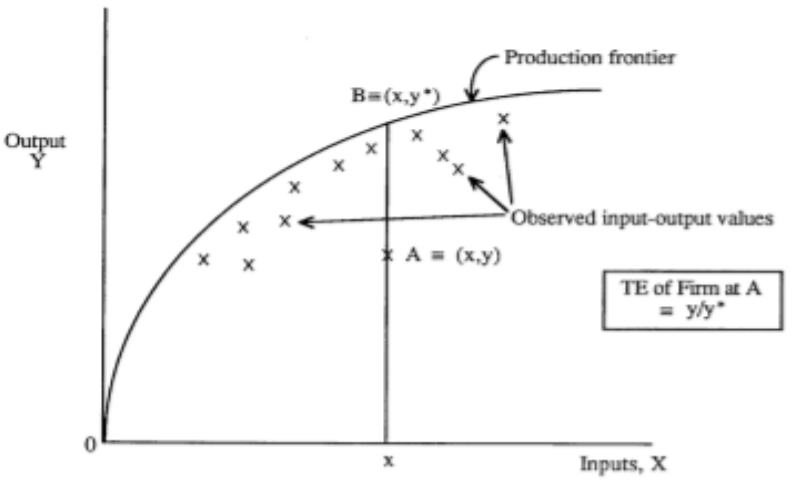

Figure 1. Technical efficiency of firms in input-output space

The horizontal axis represents the inputs, $\mathrm{X}$, associated with production of output, Y. The observed input-output values are inside the production frontier as the farms do not attain the maximum obtainable output from the inputs involved, 
given the technology. A measure of the TE of the farm that produces output $\mathrm{y}$ with input $\mathrm{x}$ (denoted by point $\mathrm{A}$ in figure 1 ) is given by $\mathrm{y} / \mathrm{y}^{*}$, where $\mathrm{y}^{*}$ is the 'frontier output' associated with the level of inputs $\mathrm{x}$ (see point B). This is a measure of TE which is conditional on the levels of the inputs involved (Battese, 1992).

The stochastic frontier production function (4) is defined for cross-sectional data. Pitt and Lee (1981) estimated a stochastic frontier production function using panel data of $\mathrm{N}$ firms over $\mathrm{T}$ periods. The model has been defined as follows:

$$
\mathrm{Y}_{\mathrm{it}}=f\left(\mathrm{X}_{\mathrm{it}} ; \beta\right) \cdot \exp \left(\mathrm{v}_{\mathrm{it}}-\mathrm{u}_{\mathrm{it}}\right) \text {; }
$$

Where, $\left(\mathrm{v}_{\mathrm{it}}-\mathrm{u}_{\mathrm{it}}\right)$ is the composite error term

$$
\mathrm{i}=1,2, \ldots, \mathrm{N}, \mathrm{t}=1,2, \ldots, \mathrm{T}
$$

Here $Y_{i t}$ represents the production of the $\mathrm{i}$-th firm $(\mathrm{i}=1,2, \ldots, \mathrm{N})$ at the $\mathrm{t}$-th period $(\mathrm{t}=1,2, \ldots, \mathrm{T}) ; \mathrm{X}_{\mathrm{it}}$ is a $(1 \mathrm{x} \mathrm{k})$ vector of values of inputs and other explanatory variables associated with the $\mathrm{i}$-th firm at the $\mathrm{t}$-th period, $\beta$ is a vector of unknown parameters for the stochastic frontier. $\mathrm{v}_{i t} \mathrm{~s}$ are assumed to be iid $\mathrm{N}\left(0, \sigma_{v}^{2}\right)$ random errors and independent from $u_{i t} s$. The $u_{i t} s$ represent non-negative random variables associated with technical inefficiency of production which are assumed to be independently distributed.

Since agricultural production always operates under uncertainty, the present study employs the stochastic production frontier approach that has been discussed above. In this framework it has been assumed that $\mathrm{u}_{\mathrm{it}} \mathrm{s}$ are non-negative random variables which are responsible for technical inefficiency in agricultural production. $u_{i t} s$ specify the inefficiency effects in the stochastic frontier production function due to factors under control of the farmers. Time plays an important role in influencing production inefficiency. Battese and Coelli (1992) proposed a simple model that can be used to estimate the time behavior of inefficiency:

$$
\mathrm{u}_{\mathrm{it}}=\{\exp [-\eta(\mathrm{t}-\mathrm{T})]\} \mathrm{u}_{\mathrm{i}}
$$

Where, $\eta$ is an unknown scalar parameter to be estimated, which determines whether inefficiency is time-varying or time-invariant, and $u_{i}$ s are assumed to be iid and truncated at zero of the $\mathrm{N}\left(\mu, \sigma_{\mathrm{u}}^{2}\right)$ distribution.

If $\eta$ is positive, then $-\eta(\mathrm{t}-\mathrm{T})=\eta(\mathrm{T}-\mathrm{t})$ is positive for $t\langle T$ and so, $\exp [-\eta(\mathrm{t}-\mathrm{T})]\rangle 1$, which implies that technical inefficiency of farm declines over time. If $\eta$ is zero, technical inefficiency of agricultural farm remains constant; if it is negative, it increases over time.

Inefficiency is assumed to be a function of a set of explanatory variables. Therefore, the technical inefficiency effect, $\mathrm{u}_{\mathrm{it}}$, in the stochastic frontier model (5) can be specified as follows:

$$
\mathrm{u}_{\mathrm{it}}=\mathrm{z}_{\mathrm{it}} \delta+\mathrm{w}_{\mathrm{it}}
$$

where the random variable $\mathrm{w}_{\text {it }}$ follows truncated normal distribution with mean zero and variance $\sigma^{2}$ such that the point of truncation is $-\mathrm{z}_{\mathrm{it}} \delta$ i.e., $\mathrm{w}_{\mathrm{it}},>-\mathrm{z}_{\mathrm{it}} \delta$. These assumptions are consistent with $\mathrm{u}_{\mathrm{it}}$ being a non-negative truncation of the $\mathrm{N}\left(\mathrm{z}_{\mathrm{it}} \delta, \sigma^{2}\right)$ distribution. After $\mathrm{u}_{\mathrm{it}} \mathrm{s}$ are estimated, the technical efficiency of the $\mathrm{i}$-th farm in the $\mathrm{t}$-th period is given by:

$$
\mathrm{TE}_{\mathrm{it}}=\operatorname{Exp}\left(-\mathrm{u}_{\mathrm{it}}\right)=\operatorname{Exp}\left(-\mathrm{z}_{\mathrm{it}} \delta \quad-\mathrm{w}_{\mathrm{it}}\right)
$$

Parameters of the stochastic frontier given by equation (5) and (in) efficiency model given by equation (6) are simultaneously estimated by using maximum likelihood estimation.

The simultaneous estimation is proposed by Battese and Coelli (1993). The likelihood function expressed in terms of variance parameters are:

$$
\sigma^{2}=\sigma^{2}{ }_{v}+\sigma^{2}{ }_{u} \text { and } \gamma=\sigma^{2}{ }_{u} / \sigma^{2}
$$

Here $\gamma$ (Gama) is the parameter that measures the discrepancy between the frontier and observed levels of output. This is interpreted as the total deviation of observed output levels from their frontier values attributable to technical inefficiency. $\gamma$ has a value between zero and one.

$\sigma_{u}{ }^{2}$ is the variance parameter that denotes deviation from the frontier due to inefficiency;

$\sigma_{\mathrm{v}}{ }^{2}$ is the variance parameter that denotes deviation from the frontier due to noise; 
$\sigma^{2}$ is the variance parameter that denotes the total deviation from the frontier.

To measure crop diversification, Simpson's Index (SID) has been considered. The Index is given as follows:

$$
\mathrm{SID}=1-\sum_{i=1}^{N} P i^{2}
$$

$P i$ is the proportionate area (or value) of the $i^{\text {th }}$ crop activity in the gross cropped area (or the total value of output),

while $\mathrm{N}$ is the number of crops.

The Simpson's index ranges between 0 and 1. If there exists complete specialization, the index moves towards zero and away from zero implies diversification. The most widely used method for measuring diversity in recent times is Simpson's index as it is easy to compute and interpret (Joshi et. al., 2004).

\subsection{Empirical Model}

A two-stage stochastic frontier approach is used in this paper, where, in the first stage, stochastic production function along with farm level technical efficiencies are estimated, and in the second stage, the determinants of such efficiency levels are identified. Maximum likelihood estimation technique is used in the first stage to estimate stochastic frontier production function. The analysis is based on data of 17 production units for the period of 23 years. The stochastic frontier production function in (5) can be viewed as a linearized version of the logarithm of the Cobb-Douglas production function (A Translog production function could have been considered instead. Here the Cobb - Douglas production function has been randomly chosen.) for panel ${ }^{\mathrm{i}}$ data:

$$
\begin{gathered}
\ln \left(\mathrm{Y}_{\mathrm{it}}\right)=\beta_{0}+\beta_{1} \ln \left(\mathrm{L}_{\mathrm{it}}\right)+\beta_{2} \ln \left(\mathrm{HL}_{\mathrm{it}}\right)+\beta_{3} \ln \left(\mathrm{F}_{\mathrm{it}}\right)+\beta_{4} \ln \left(\mathrm{IR}_{\mathrm{it}}\right)+\beta_{5} \ln \left(\mathrm{Cr}_{\mathrm{it}}\right)+\varepsilon_{i t} \\
\varepsilon_{\mathrm{it}}=\mathrm{v}_{\mathrm{it}}-\mathrm{u}_{\mathrm{it}}, \quad \mathrm{u}_{\mathrm{it}} \geq 0 \quad \mathrm{i}=1,2, \ldots ., \mathrm{N}, \mathrm{t}=1,2, \mathrm{~T}
\end{gathered}
$$

$\mathrm{Y}_{\mathrm{it}}$ represents the quantity of output (in 000 ' tons) of the i-th unit in year $t$,

' $\mathrm{L}_{\mathrm{it}}$ ' represents cultivated land (in 000 ' hectares) of the $\mathrm{i}$-th unit in year $\mathrm{t}$,

' $\mathrm{HL}_{\mathrm{it}}$ ' represents the total human labor (in 000' man-days) of the $\mathrm{i}$-th unit in year $\mathrm{t}$,

' $I R_{\mathrm{it}}$ ' represents cultivated land under irrigation (in 000 ' hectares) of the $\mathrm{i}$-th unit in year $\mathrm{t}$,

' $F_{\text {it }}$ ' represents the quantity of fertilizer used ( 000 ' tons of NPK) of the i-th unit in year $t$,

' $\mathrm{Cr}_{\text {it }}$ ' represents Credit facilities (Dummy used as a proxy variable) of the i-th unit in year $\mathrm{t}$,

$\mathrm{u}_{\mathrm{it}}$-non-negative time-variant random variables capturing technical inefficiency,

$v_{i t}$-random variables of $i$-th unit in year $t$ reflecting effect of noise (factors not under farmers' control)

The technical efficiency of the i-th farm in the t-th year can be calculated as:

$$
\mathrm{TE}_{\mathrm{it}}=\exp \left(-\mathrm{u}_{\mathrm{it}}\right)
$$

In the second stage, the study uses the maximum likelihood estimation (MLE) technique to identify the determinants of TE by regressing different variables against the TE values obtained from Equation 8. In this estimation technique, the farm (district) specific TE estimates are used as dependent variables. The specification of the empirical model is given by

$$
\mathrm{TE}=\delta_{0}+\delta_{1} \ln \text { Labint }_{\mathrm{it}}+\delta_{2} \ln \operatorname{Irrint}_{\mathrm{it}}+\delta_{3} \ln \text { Fertint }_{\mathrm{it}}+\underset{\mathrm{AEx}_{\mathrm{it}}+\mathrm{e}_{\mathrm{it}} \delta_{5} \mathrm{Cnd}_{\mathrm{it}}+\delta_{5} \ln \mathrm{Ah}_{\mathrm{it}}+\delta_{6} \mathrm{Sf}_{\mathrm{it}}+\delta_{7} \ln \mathrm{Rm}_{\mathrm{it}}+\delta_{8} \ln \mathrm{Edu}_{\mathrm{it}}+\delta_{9} \ln }{(9)}
$$

Where, Labint, Fertint, Irrint are the representation of labor intensity, fertilizer intensity and irrigation intensity respectively. Cd is the crop diversification, Sf and Ah are percentage of small landholders and average size of holding respectively. $\mathrm{Rm}$ represents number of rural markets, Edu is the rural literacy rate (a proxy for education), and $\mathrm{AEx}_{\mathrm{it}}$ is the agricultural extension (dummy used for AEx).

The study also uses principle component regression (PCR) method, where it begins with principal component analysis (PCA) to reduce the dimensions of the variables or to overcome the problem of multi co-linearity. The number of principal component used in the PCR model have been selected based on the cumulative proportion of the total variability in the range from 65 percent to 95 percent In this context the principal components are considered as 
regressor variables and the dependent variable is technical efficiency. Dummy variables in the PCR model overcome the problem of error of heterogeneity. The PCR model with dummy variables give a better model than the PCR model without dummy variables (Sahriman et. al, 2014).

Thus, the technical efficiency has been specified as a function of the following principal components. The model for principal component regression is given by Equation (10):

$$
\mathrm{TE}=\beta_{0}+\beta_{1} \mathrm{PC} 1+\beta_{2} \mathrm{PC} 2+\beta_{3} \mathrm{PC} 3+\beta_{4} \mathrm{PC} 4+\beta_{5} \text { Dummy }+€_{i} \ldots \ldots
$$

$\mathrm{PC}=$ principal components, Dummy $=$ dummy use for agricultural extension

$$
\beta_{i}=\text { all Co-efficients }
$$

Where, $i=0,1,2,3,4,5$

\section{Results and Discussion}

\subsection{Descriptive Statistics}

The descriptive statistics of panel data used in stochastic functions as well as TE model are given in table 1. The minimum level of production is 194.19 thousand tones and maximum level of production is 5264.55 thousand tons. Mean and standard deviation of production are 1874.55 thousand tons and 1107.40 respectively. The minimum uses of inputs like cultivated land, labor, irrigation and fertilizer consumption are 70.80 thousand hectares, 11385.04 thousand man-days, 3.56 thousand hectares, and 11.90 thousand tons respectively whereas maximum uses of cultivated land, labor and fertilizer consumption are 955.97 thousand hectare, 155920.30 thousand man-days, 432.87 thousand hectares and 196.20 thousand tons respectively. Mean of cultivated land, labor, Irrigation and fertilizer consumption are 501.64 thousand hectare, 80983.47 thousand man-days, 167.21 thousand hectares and 69.96 thousand tons respectively. The standard deviation of these variables are 203.98, 34796.23, 108.94 and 35.209 respectively. The dummy variable (D) is used in SFA as a proxy variable for agricultural credit. The study has used $\mathrm{D}=0$ before the $2001-02$ and $\mathrm{D}=1$ for 2001-02 onward. Mean and standard deviation of this variable are 0.57 and 0.50 .

\begin{tabular}{|c|c|c|c|c|}
\hline & Minimum & Maximum & Mean & Std. Deviation \\
\hline Production (000'tons) & 194.193 & 5264.545 & 1874.551 & 1107.402 \\
\hline Land (000'Ha) & 70.800 & 955.965 & 501.643 & 203.983 \\
\hline Labor (000' Man-days) & 11385.037 & 155920.301 & 80983.468 & 34796.225 \\
\hline Irrigation $\left(000^{\prime} \mathrm{Ha}\right)$ & 3.560 & 432.866 & 167.209 & 108.935 \\
\hline Fertilizer $\left(000^{\prime}\right.$ tons $)$ & 11.900 & 196.200 & 69.958 & 35.209 \\
\hline Agricultural Credit (Dummy) & 0.000 & 1.000 & 0.565 & 0.496 \\
\hline Technical Efficiency & 0.291 & 0.991 & 0.605 & 0.148 \\
\hline Labor Intensity (man-days/Ha) & 103.496 & 199.903 & 159.586 & 15.351 \\
\hline Irrigation Intensity (\%) & 2.687 & 89.192 & 32.185 & 16.993 \\
\hline Fertilizer Intensity (kg./Ha) & 32.314 & 455.381 & 151.834 & 71.731 \\
\hline Crop Diversification & 0.223 & 0.863 & 0.664 & 0.148 \\
\hline Size of Holding ( $\mathrm{Ha}$ ) & 0.430 & 1.685 & 0.857 & 0.264 \\
\hline Proportion of Small Landholders & 86.543 & 99.785 & 94.702 & 3.160 \\
\hline Number of Market & 2.000 & 114.000 & 35.601 & 27.084 \\
\hline Farmers' Education (\%) & 24.232 & 89.031 & 63.579 & 11.871 \\
\hline Agricultural Extension (Dummy) & 0.000 & 1.000 & 0.565 & 0.496 \\
\hline Valid N (list-wise) & 391 & & & \\
\hline
\end{tabular}

Table 1. Descriptive Statistics of SFA Variables and TE Determinant

Source: Authors' Calculation

In the TE model, the dependent variable is technical efficiency which varies between 0.291 and 0.991 , mean and standard deviation of TE are 0.605 and 0.148 respectively. The Minimum values of labor intensity, irrigation intensity, fertilizer intensity, crop diversification, size of holding, proportion of small landholders, number of markets and farmers' education level are 103.496 man-days per hectare, 2.687 percent, $32.314 \mathrm{~kg}$./hectare, $0.223,0.430$ hectare, 86.543 percent, 2.000 and 24.232 percent respectively whereas maximum values of these variables are 199.903 man-days per hectare, 89.192 percent, $455.381 \mathrm{~kg} . /$ hectare, $0.863,1.685$ hectare, 99.785 percent, 114.000 and 89.031 percent respectively.

The mean and standard deviation of labor intensity $(159.586,15.351)$, irrigation intensity $(32.185,16.993)$, fertilizer intensity $(151.834,71.731)$, crop diversification $(0.664,0.148)$, size of holding $(0.857,0.264)$, proportion of small 
landholders $(94.702,3.160)$, number of markets $(35.601,27.084)$ and farmers' education $(63.579,11.871)$ are shown in table 1.

Maximum likelihood estimation of the parameters of Cobb-Douglas stochastic frontier production function and the technical efficiency effect model, given by equations (8) and (9), respectively, have been obtained using Frontier version 4.1 (Coelli, 1996) software. Estimates of parameters as well as the SE and tratio of the maximum likelihood estimation of agricultural farms of West Bengal have been presented in Tables 2, 3 and 6.

\subsection{Estimation of Stochastic Frontier Production Function}

The maximum-likelihood estimates of the parameters for time-variant and time-invariant Cobb-Douglas stochastic frontier production function with the assumptions of half normal and truncated normal distribution are presented in Tables 2 and 3 . The half-normal and a truncated normal distributions have been considered to measure the presence of inefficiency in the model. Here, the log-likelihood ratio of the half-normal distribution is the null hypothesis $\left(\mathrm{H}_{0}: \mu=0\right)$, while the $\log$-likelihood ratio of the truncated normal distribution is the alternative hypothesis $\left(\mathrm{H}_{1}: \mu \neq 0\right)$. Similarly, another hypothesis that inefficiency is time-invariant (i.e., $\eta=0$ ) will be tested. The model will be estimated first by assuming time-variant (i.e., $\eta \neq 0$ ) inefficiency; then restricted by modelling the frontier as time-invariant (Hasan, et. al., 2012).

The estimates of the parameters with time-varying inefficiency effects for truncated and half-normal distributions are presented in Table 2. The results depict that the coefficients in both the half normal and the truncated normal distribution in the time-variant model are 0.443 and 0.510 for land, 0.397 and 0.334 for labor, 0.066 and 0.068 for irrigation, 0.039 and 0.025 for fertilizer, 0.285 and 0.292 for credit, respectively. The estimated coefficients for all the inputs are positive. The coefficients of the inputs have signs as expected which confirm the expected positive relationship between land, labor, fertilizer, irrigation and credit with agricultural production. All these coefficients are statistically significant. The estimated values of the parameters of Cobb-Douglas frontier production function obtained with the assumptions of truncated and half-normal distributions are almost similar. The log likelihood functional values also are 127.26 and 132.66 in half normal distribution and truncated normal distribution respectively which are very close to each other. For a truncated normal distribution, $\gamma$ is estimated to be 0.489 and for a half-normal distribution it is 0.805 . Both the values are positive and significant. It can be interpreted that 48.90 percent variation in farm output of West Bengal agriculture is due to the differences in technical inefficiency when truncated normal distribution is considered and 80.50 percent variation arises when half-normal distribution is chosen. From Table 2, we can also say that the estimates of $\sigma$ are 0.3585 and 0.2156 for half-normal and truncated normal distribution respectively with a time-variant model, which are significantly positive indicating that the assumptions of truncated and half-normal distributions are correct.

Table 2. Maximum-Likelihood Estimates of the Cobb-Douglas Stochastic Frontier Production Function Operate with Time-Variant

\begin{tabular}{|c|c|c|c|c|c|c|c|}
\hline \multirow[b]{2}{*}{ Variables } & \multicolumn{4}{|c|}{ Half Normal Distribution } & \multicolumn{3}{|c|}{ Truncated Normal Distribution } \\
\hline & Parameter & Coefficients & SE & T-value & Coefficients & SE & T-value \\
\hline Constant & $\beta_{0}$ & 0.067 & 0.610 & 0.111 & 0.422 & 0.637 & 0.662 \\
\hline Ln Land & $\beta_{1}$ & $0.443 *$ & 0.132 & 3.353 & $0.510 *$ & 0.149 & 3.417 \\
\hline Ln Labor & $\beta_{2}$ & $0.397 *$ & 0.120 & 3.315 & $0.334 *$ & 0.129 & 2.592 \\
\hline Ln Irrigation & $\beta_{3}$ & $0.066^{*}$ & 0.022 & 2.955 & $0.068 *$ & 0.026 & 2.626 \\
\hline Ln Fertilizer & $\beta_{4}$ & $0.039 * * *$ & 0.029 & 1.344 & 0.025 & 0.031 & 0.808 \\
\hline Ln Credit & $\beta_{5}$ & $0.285^{*}$ & 0.029 & 9.980 & $0.292 *$ & 0.026 & 11.427 \\
\hline Sigma Squared & $\sigma^{2}$ & $0.129 *$ & 0.044 & 2.947 & $0.047 *$ & 0.015 & 3.206 \\
\hline Gama & $\gamma$ & $0.805^{*}$ & 0.069 & 11.720 & $0.489 *$ & 0.081 & 6.014 \\
\hline Sigma & $\sigma$ & 0.359 & & & 0.217 & & \\
\hline$M u$ & $\mu$ & & & & 0.303 & 0.101 & 2.984 \\
\hline Eta & $\eta$ & 0.044 & 0.005 & 9.218 & 0.042 & 0.004 & 10.025 \\
\hline Log likelihood Function & & $127.26\left(\mu_{0}\right)$ & & & $132.66\left(\mu_{1}\right)$ & & \\
\hline LR ratio & & 10.734 & & & & & \\
\hline
\end{tabular}

$*, * * * * *$ Significance level at 1 per cent, 5 per cent and 10 per cent

S.E $=$ Standard Error

Source: Authors' Calculation

The results in Table 3 show that the maximum-likelihood estimates of the parameters with time-invariant inefficiency effects for half-normal and truncated normal distributions are 0.461 and 0.541 for land, 0.270 and 0.197 for labor, 0.123 and 0.122 for irrigation, 0.132 and 0.125 for fertilizer, 0.520 and 0.525 for credit, respectively. The signs of the coefficients of all inputs are positive. All these coefficients in both the distribution are statistically significant. The log likelihood functional values of the two distributions are 77.089 and 83.308, which are nearly similar. The values of $\gamma$ are 
found to be positive and significant in both the cases of half-normal and truncated normal distributions with time-invariant model and the values are 0.878 and 0.607 respectively. Therefore, we can say that in the case of time-invariant model 60.70 percent variation in farm output of West Bengal agriculture is due to the differences in technical inefficiency from truncated normal distribution and 87.80 percent variation is found when half-normal distribution is considered. Table 3 also depicts that the estimates of $\sigma$ are 0.523 and 0.284 for half-normal and truncated normal distribution respectively in the time-invariant model, which are significantly positive.

The null hypothesis of the model is that there is no technical inefficiency effect. In other words, $\mathrm{H}_{0}: \sigma_{\mathrm{u}}{ }^{2}=0$ and the alternative hypothesis is $\mathrm{H}_{1}: \sigma_{\mathrm{u}}^{2}>0$.

A number of test statistics are available for testing this hypothesis. Here, the generalized likelihood-ratio test has been selected for testing alternative hypothesis. i.e.,

$\mathrm{H}_{0}: \gamma=0$ and the alternative hypothesis is $\mathrm{H}_{1}: \gamma>0$ (with $\gamma=\sigma_{\mathrm{u}}{ }^{2} / \sigma^{2}$ where, $\sigma^{2}=\sigma_{\mathrm{u}}{ }^{2}+\sigma_{\mathrm{v}}{ }^{2}$ )

Table 3. Maximum-Likelihood Estimates of the Cobb-Douglas Stochastic Frontier Production Function Operate with Time-invariant

\begin{tabular}{|c|c|c|c|c|c|c|c|}
\hline & & \multicolumn{3}{|c|}{ Half Normal Distribution } & \multicolumn{3}{|c|}{ Truncated Normal Distribution } \\
\hline Variables & Parameter & Coefficients & $\mathrm{SE}$ & T-value & Coefficients & $\mathrm{SE}$ & T-value \\
\hline Constant & $\beta_{0}$ & 0.536 & 0.799 & 0.671 & 0.932 & 0.863 & 1.080 \\
\hline Ln Land & $\beta_{1}$ & $0.461 *$ & 0.142 & 3.245 & $0.541^{*}$ & 0.154 & 3.525 \\
\hline Ln Labor & $\beta_{2}$ & $0.270 * *$ & 0.138 & 1.959 & $0.197 * * *$ & 0.150 & 1.311 \\
\hline Ln Irrigation & $\beta_{3}$ & $0.123^{*}$ & 0.024 & 5.043 & $0.122 *$ & 0.024 & 5.045 \\
\hline Ln Fertilizer & $\beta_{4}$ & $0.132 *$ & 0.032 & 4.152 & $0.125 *$ & 0.034 & 3.628 \\
\hline Ln Credit & $\beta_{5}$ & $0.520^{*}$ & 0.023 & 22.604 & $0.519 *$ & 0.024 & 22.044 \\
\hline Sigma Squared & $\sigma^{2}$ & $0.274^{*}$ & 0.098 & 2.810 & $0.081 *$ & 0.013 & 6.088 \\
\hline Gama & $\gamma$ & $0.878^{*}$ & 0.045 & 19.645 & $0.607 *$ & 0.056 & 10.805 \\
\hline Sigma & $\sigma$ & 0.523 & & & 0.284 & & \\
\hline$M u$ & $\mu$ & - & - & - & 0.443 & 0.085 & 5.198 \\
\hline Eta & $\eta$ & - & - & - & - & - & - \\
\hline Log likelihood Function & & \multirow{2}{*}{\multicolumn{3}{|c|}{$77.089(\mu=\eta=0)$}} & \multirow{2}{*}{\multicolumn{3}{|c|}{$\begin{array}{l}83.308\left(\eta_{0}, \mu \neq 0\right) \\
98.63\end{array}$}} \\
\hline LR Ratio & & & & & & & \\
\hline
\end{tabular}

$*, * *, * * *$ Significance level at 1 per cent, 5 per cent and 10 per cent

S.E $=$ Standard Error

Source: Authors' Calculation

A series of formal hypothesis tests have been conducted to work out the distribution of random variables related to the existence of technical inefficiency and also the residual error term. These are tested through imposing restrictions on the model and the generalized likelihood-ratio statistic have been used to determine the significance of the restrictions. The generalized likelihood ratio statistic defined by the test, requires the estimation of the model under both the null and alternative hypothesis. Under the null hypothesis the model is equivalent to the traditional average response function, without the technical inefficiency effect, $\mathrm{u}_{\mathrm{i}}$. The test statistic is calculated as

$$
L R(\lambda)=-2\left\{\ln \left[L\left(H_{0}\right) / L\left(H_{1}\right)\right]\right\}=-2\left\{\ln \left[L\left(H_{0}\right)\right]-\ln \left[L\left(H_{1}\right)\right]\right\}
$$

Where $L\left(H_{0}\right)$ and $L\left(H_{1}\right)$ are the values of the likelihood function for the frontier model under the null and the alternative hypothesis respectively. Test Statistic is calculated in Frontier and the critical value of a test of size $\alpha_{0,05}$ is 2.7 .

If the null hypothesis involves $\gamma=0$, expressing that the technical inefficiency effects are not present in the model, then, $\lambda$ has a mixed chi-square distribution with the number of degrees of freedom given by the number of restrictions imposed (Battese and Coelli,1993) because $\gamma=0$ is a value on the boundary of the parameter space for $\lambda$. If the parameter $\mu$ is restricted to zero then the half-normal distribution is the effective model for inefficiency. On the other hand if $\eta$ is restricted to zero in the model then the model is one with time-invariant inefficiency effect.

Table 4 shows that all the values of test statistics are more than their critical values. It implies that all the null hypotheses are rejected and the alternative hypotheses are accepted. In our study, $\gamma$ is always greater than zero and statistically significant whatever be the hypothesis. Therefore, inefficiency exists in the agricultural production of West Bengal. 
Table 4. Test of Hypothesis for the parameters of the Stochastic Frontier Production Function

\begin{tabular}{|c|c|c|c|c|}
\hline Hypothesis & Log Likelihood Function & Test statistics & Critical Value & Decision \\
\hline$H_{0}: \gamma=0$ & 20.49 & 224.27 & 7.045 & Rejected \\
\hline$H_{0}: \mu=0, \eta \neq 0$ & 127.26 & 10.73 & 5.138 & Rejected \\
\hline$H_{0}: \mu=\eta=0$ & 77.09 & $12.48 \quad(1)$ & 2.706 & Rejected \\
\hline$H_{0}: \eta=0, \mu \neq 0$ & 83.31 & $98.63 \quad(2)$ & 5.138 & Rejected \\
\hline
\end{tabular}

Notes. All critical values are at $5 \%$ level of significance. The critical value for this test involving $\gamma=0$ is obtained from table of Kodde and Palm (1986).

Source: Authors' Calculation

We also tried to check the robustness of the result by using maximum likelihood function instead of the ordinary least square. The hypothesis $\mu=0$, is rejected, which means half-normal distribution is not suitable for our analysis. The alternative distribution of a truncated normal is the effective distribution for our analysis. Similarly, $\eta$ positive is the accepted proposition in our model. So it can be said that the maximum-likelihood estimates of the Cobb-Douglas stochastic frontier production function in a time-variant truncated normal distribution is the suitable model for the measurement of technical inefficiency in West Bengal agriculture. The estimates for the parameters of the time-varying inefficiency model in Table 2 indicate that the estimates for $\eta$ parameter in a truncated normal distribution is positive and significant, the technical efficiency tends to increase over time and vice versa. The variance ratio (Gama) shows that 48.90 percent of the differences between the observed output and the frontier level of output has been caused by differences in farm's technical inefficiencies, while the remaining variation is due to factors out of farmers' control.

The estimated results of time variant truncated normal distribution (Table 2) also indicate the relative importance of inputs in agricultural production of West Bengal. The land is the most important factor of production with an elasticity of 0.510 , followed by labor with an elasticity of 0.334 , the elasticity of availability of credit is 0.292 and that of irrigation and fertilizer consumption are 0.068 and 0.025 respectively. The sum of the partial elasticities with respect to each input estimated by the maximum likelihood estimator of the Cobb-Douglas stochastic production function is 1.228. The agricultural farms, therefore, in West Bengal exhibit increasing returns to scale. This implies that an increase in all available inputs leads to a more than proportionate increase in farm output (Kompas and Chu, 2006).

\subsection{Farm Level Technical Efficiency}

Table 5 indicates that the average technical efficiency of different agricultural production units (districts) of West Bengal have increased over the time periods considered. In the decade of 2010, all the production units have produced more efficiently than in the previous decades. The magnitude of technical efficiency of all the districts is more than 0.599 during the decade of 2010. Among these production units, Hooghly shows the highest technical efficiency and Purulia exhibits the lowest efficiency during triennium 1993-94, 2003-04 and 2013-14. The mean efficiencies are 0.478, 0.609 and 0.719 during the triennium ending 93-94, 2003-04 and 2013-14 respectively.

Table 5. Decade-wise Average Efficiency of Agricultural Production Units in West Bengal

\begin{tabular}{cccc}
\hline Units & Triennium Ending1993-94 & Triennium Ending 2003-04 & Triennium Ending 2013-14 \\
\hline Hooghly & 0.980 & 0.986 & 0.991 \\
Bardhaman & 0.679 & 0.775 & 0.846 \\
Paschim Midnapore & 0.596 & 0.711 & 0.799 \\
Bankura & 0.581 & 0.700 & 0.791 \\
Birbhum & 0.461 & 0.601 & 0.716 \\
Darjeeling & 0.460 & 0.600 & 0.715 \\
Murshidabad & 0.449 & 0.590 & 0.707 \\
North 24 Parganas & 0.448 & 0.589 & 0.706 \\
Howrah & 0.431 & 0.575 & 0.695 \\
Purba Midnapore & 0.424 & 0.569 & 0.690 \\
Nadia & 0.423 & 0.568 & 0.690 \\
Coochbihar & 0.404 & 0.551 & 0.676 \\
Malda & 0.380 & 0.529 & 0.658 \\
Jalpaiguri & 0.377 & 0.527 & 0.656 \\
West Dinajpur & 0.370 & 0.520 & 0.651 \\
South 24 Parganas & 0.355 & 0.506 & 0.639 \\
Purulia & 0.306 & 0.459 & 0.599 \\
Mean Efficiency & 0.478 & 0.609 & 0.719 \\
\hline
\end{tabular}

Source: Authors' Calculation 
The table 5 also indicates that during triennium ending 1993-94, the magnitude of technical efficiency of all the farms are below 0.60, except Hooghly (0.980) and Bardhaman (0.679). Fifteen farms out of seventeen have shown low levels of technical efficiency during this period. In other words, 88.23 percent of farms have technical efficiency below 0.60. However, the value of technical efficiency of all farms during triennium ending 2013-14, are above 0.60. In this period all farms show comparatively higher level of technical efficiency.

\subsection{The Determinants of Technical Efficiency}

Agricultural production level which are technically inefficient, reduces farmers' income and profit. Estimation of technical efficiency of farming helps farmers to evaluate whether their farms are technically efficient or not subject to the available resources. The study of technical efficiency is likely to enlighten the farmers about the better use of the farming inputs and improves their production efficiency through higher level of production. A vital question in this context is how to improve farmers' technical efficiency using the resources available to them. In order to find a solution to this problem the study further analyzes the determinants of technical efficiency.

\section{A. Maximum Likelihood Estimation:}

Maximum likelihood estimation is used to estimates the $\delta$ coefficients of equation (9) for determinants of technical efficiency. A positive sign of the estimated parameters indicate an increase in TE with the increase in the levels of the variables chosen and vice versa. A negative sign implies that technical efficiency decreases with an increase in the variables considered. The results are presented in table 6 .

The coefficients of input intensity like labor, irrigation and fertilizer consumption have a positive sign. All these coefficients are statistically significant. The technical efficiency is enhanced when fertilizer consumption and irrigation facility increase along with labor employment per unit of land. Crop diversification here has been defined as the policy related variable. The estimated coefficients of this variable is positive and statistically significant at 1 percent level. This implies that greater crop diversification is associated with a higher level of technical efficiency. The farms characterized by higher diversification are more efficient. This result is consistent with the findings of Ahmadzai (2004), Manjunatha et. al. (2013), Ogundari (2013), for Afghanistan, India, and Nigeria respectively.

Table 6. Maximum Likelihood Estimates of the Determinants of Technical Efficiency of Agricultural Farm in West Bengal

\begin{tabular}{lllll}
\hline Variables & Parameter & Coefficient & SE & t value \\
\hline $\begin{array}{l}\text { Constant } \\
\text { Input Intensity Variables }\end{array}$ & $\delta_{0}$ & -1.137 & 1.040 & -1.0933 \\
$\begin{array}{l}\text { Labor Intensity } \\
\text { Irrigation Intensity }\end{array}$ & $\delta_{1}$ & $0.134^{* *}$ & 0.081 & 1.660 \\
$\begin{array}{l}\text { Fertilizer Intensity } \\
\text { Policy Related Variable }\end{array}$ & $\delta_{2}$ & $0.130^{*}$ & 0.012 & 10.809 \\
Crop Diversification & $\delta_{3}$ & $0.062^{*}$ & 0.017 & 3.623 \\
Infrastructural Variable & & & 0.028 & 6.731 \\
Size of Holding & $\delta_{4}$ & $0.187^{*}$ & 0.032 & 2.380 \\
Proportion of Small Landholder & $\delta_{5}$ & $0.076^{*}$ & 0.217 & -3.066 \\
Number of Market & $\delta_{6}$ & $-0.666^{*}$ & 0.010 & 6.729 \\
Institutional Variables & $\delta_{7}$ & $0.065^{*}$ & 0.044 & 11.225 \\
Farmers' Education & & & 0.015 & 7.797 \\
Agricultural Extension & $\delta_{8}$ & $0.493^{*}$ & 0.001 & 14.070 \\
Sigma Square & $\delta_{9}$ & $0.121^{*}$ & 0.000 & 23.710 \\
Gama & $\sigma^{2}$ & $0.015^{*}$ & & \\
Log Likelihood Function & $\gamma$ & $0.0008^{*}$ & & \\
Log Likelihood Ratio & LF & 292.518 & & \\
Iteration & LR & 64.2787 & 2.000 & \\
\hline
\end{tabular}

$*, * *, * * *$ Significance level at 1 per cent, 5 per cent and 10 per cent

S.E $=$ Standard Error

Source: Authors' Calculation

The size of holdings, the proportion of small landholders and the number of agricultural markets are the infrastructural variables. The coefficients of farm size and the number of agricultural markets are significantly positive. This implies that large farms are more technically efficient than small farms. This result however contradicts that obtained by Yotopoulos and Lau (1971) that smaller farms are more efficient in cost allocation. The result also does not support the observation of Van-Zyl et. al. (1995) that commercial farms could be significantly more efficient if they become smaller. 
But the result is in coincidence with that of Laha (2013) that large farms having access to formal credit are technically more efficient than smaller ones. In an asset based lending policy, land size often determines the probability of access to credit. Hence large farmers having access to credit are able to utilize it properly by acquiring required inputs and thereby attain technical efficiency which small farms cannot. Cornia (1985) also obtained similar result. Initially, the factor use intensity gave small farms a productivity advantage over large farms. However, after the advent of Green Revolution, the small farms might have lost this advantage. In the absence of technical extension and access to credit facility, small farmers could not use the Green Revolution technology. The analysis also shows that technical efficiency in agricultural can be enhanced by expanding agricultural markets. With greater access to markets, farmers can easily buy inputs and sell their outputs at a lower cost. The proportion of small farmers and technical efficiency are inversely related as the coefficient of the variable the 'proportion of small farmers' is significantly negative. Hence it can be concluded that a decline in the proportion of small farmers leads to a rise in the technical efficiency. It is true that small farmers are unable to cultivate as efficiently as large farmers as their resources are limited.

The coefficients of institutional variables including farmers' education and agricultural extension are positively correlated with technical efficiency. All these coefficients are statistically significant. Education has a positive and significant impact on technical efficiency. Educated or knowledgeable farmers use their inputs more efficiently compared to uneducated farmers. Here education means vocational training and adult education. Therefore the suitable policy would be to strengthen vocational and adult education in rural areas through active government initiative (Ahmadzai, 2004). The coefficient of agricultural extension has a significantly positive value. The result indicates that facilities of agricultural extension mainly scientific research and introduction of new kinds to agricultural practice improve farmers' efficiency. These results support the observations of Li Zongzhang and Li Dingan (2011). The empirical results of their study suggest that agricultural extension has a positive impact on technical efficiency. The provinces having more agricultural extension facilities along with larger number of extension personnel exhibit higher production efficiency. Therefore the present study suggests that the central and state government should take initiative to provide greater agricultural extension facilities. This can be done through organizing wider range of communication and learning activities for rural people by educators from different disciplines including agriculture, agricultural marketing, and health and business studies.

\section{B. Principal Component Analysis:}

In this section principal component analysis has been used to estimates the different principal components (PC) of equation (10) as determinants of technical efficiency. The PCA has been used as an alternative statistical tool to compare the results derived from MLE.

Here, eight variables have been taken into consideration in principal component analysis (PCA) of which maximum variability has been displayed by the first four Eigen values and the corresponding four components have been picked up for further analysis. The principal component regression (PCR) has been done on panel data from 17 farm (districts) for the period of 23 years (1991-92 to 2013-2014). Rotated component matrix of independent variables (determinants of Technical Efficiency) with different factor loadings for selected agricultural farms in West Bengal have been presented in Annexure Table 1. This has been calculated using SPSS software. The factor loadings represent the weights assigned to each of the variables in the linear combination corresponding to each Eigen value. The values of factor loadings obtained for each principal component indicate that all the variables are significant.

Table 7 shows the first four Eigen value of which the first one (2.399) captures maximum variability (29.987 percent). The second Eigen value (1.596) indicates the second highest variability (19.946 percent). Likewise the third and the fourth components capture 15.811 percent and 12.940 percent variability respectively and so on. There are eight components altogether of which the first four Eigen values together capture maximum variability (78.683 percent).

Table 7. Eigen Value and Percentage of Variance of the Determinant of Technical Efficiency of Agricultural Farm in West Bengal

\begin{tabular}{lcccc}
\hline & Factor 1 & Factor 2 & Factor 3 & Factor 4 \\
\hline Eigen value & 2.399 & 1.596 & 1.265 & 1.035 \\
Variance (\%) & 29.987 & 19.946 & 15.811 & 12.940 \\
Cumulative (\%) & 29.987 & 49.933 & 65.744 & 78.683 \\
\hline
\end{tabular}

The first component in table1 in the Annexure shows that the weights assigned to the first variable (size of holding) is 0.649 , the second variable (labor intensity) is 0.628 and for the third variable (Proportion of small and marginal landholders) is -0.946 . Similarly, fertilizer intensity $(0.818)$ and education $(0.803)$ are weights attached for the second 
component. The weight for third component is the irrigation intensity $(0.905)$. The number of agricultural markets $(0.835)$ and crop diversification $(0.660)$ are the weights assigned to the fourth component.

Table 8. Principal Component Regression Statistics of the Determinant of Technical Efficiency of Agricultural Farm in West Bengal

\begin{tabular}{|c|c|c|c|c|c|c|}
\hline & Constant & PC 1 & PC 2 & PC 3 & $\mathrm{PC} 4$ & Dummy \\
\hline Coefficient & $0.549 *$ & $0.058^{*}$ & $0.412 *$ & $0.457 *$ & $0.346^{*}$ & $0.327 *$ \\
\hline t-value & 81.067 & 2.090 & 13.141 & 16.132 & 12.371 & 10.212 \\
\hline F Statistic & $181.70(6,385)$ & & & & & \\
\hline R-Square & 0.702 & & & & & \\
\hline Adjusted R Square & 0.698 & & & & & \\
\hline $\mathrm{S} E$ of the Estimate & 0.081257 & & & & & \\
\hline D-W Statistic & 1.657 & & & & & \\
\hline
\end{tabular}

In table 8 , the principal component regression results explain that all the coefficients and intercepts are positive and statistically significant. The results indicates that the variables in the first, the second, the third and the fourth rotated factors, namely, the size of holding, labor intensity, fertilizer intensity, education, irrigation intensity, agricultural markets and crop diversification have positive impacts on technical efficiency. However, the variable 'proportion of small and marginal landholders' influenced technical efficiency in a negative way. The dummy used for agricultural extension has a significantly positive impact on technical efficiency.

The computed $R^{2}$ and the adjusted $R^{2}$ in this PCR model are 0.702 and 0.698 respectively. The result indicates that around 70 percent of the variation in dependent variable are explained by these four principal components. The $\mathrm{F}$ calculated value is 181.70 and DW statistics is 1.657 .

Therefore, it can be concluded that whatever be the statistical technique, be it the maximum likelihood estimation or the principal component regression analysis the findings are similar.

\section{Conclusion}

In this study, the district level TE of West Bengal and its determinants have been analysed for the post-liberalization period from 1991-92 to 2013-14. The stochastic frontier approach has been used as the analytical tool. It has also been attempted to check the robustness of the results under alternative specifications by using maximum likelihood function instead of ordinary least square. The findings indicate that the truncated normal distribution with time-variant model is suitable for the measurement of technical inefficiency for West Bengal agriculture. The estimated variance ratio indicates that around 48.90 percent of the differences between the observed output and the estimated output has been caused by differences in farms' technical inefficiencies, while the remaining variation is due to factors out of the control of the farmers. The technical efficiency of different production units have increased over time. Among the production units Hooghly shows the highest technical efficiency while Purulia exhibits the lowest efficiency. The study also shows that the sum of the coefficients of inputs in the production function (Cobb-Douglas type) is greater than one implying the presence of increasing return to scale in West Bengal agriculture.

Among the determinants of technical efficiency, the proportion of small landholders alone has significant negative effects but the other determinants show positive and significant impact on technical efficiency. This indicates that greater crop diversification in large farm is associated with higher levels of technical efficiency. Education (vocational training and adult education) and agricultural extension (scientific research and new knowledge to agricultural practice) also have positive and significant impact on technical efficiency as expected. The paper suggests that to reap the advantage of TE, more crop diversification should be practiced in West Bengal backed by improved farmers' literacy.

\section{References}

Ahmadzai, H. (2004). Crop Diversification and Technical Efficiency in Afghanistan: Stochastic Frontier Analysis, CREDIT, Research Paper, No. 17/04.

Battese, G. E. (1992). Frontier production functions and technical efficiency: a survey of empirical applications in agricultural economics. Agricultural Economics, 7, 185-208. https://doi.org/10.1016/0169-5150(92)90049-5

Battese, G. E., \& Coelli, T. J. (1992). Frontier Production Functions, Technical Efficiency and Panel Data: with Application to Paddy Farmers in India, Journal of Productivity Analysis, 3, 153-169. https://doi.org/10.1007/BF00158774

Battese, G. E., \& Coelli, T. J. (1993). A Stochastic Frontier Production Function Incorporating a Model for Technical Inefficiency Effects. Department of Econometrics. University of New England. 
Battese, G. E., \& Coelli, T. J. (1995). A Model for Technical Inefficiency Effects in a Stochastic Frontier Production Function for Panel Data. Empirical Economics, 20(2), 325-332. https://doi.org/10.1007/BF01205442

Coelli, T. J. (1996). A Guide to Frontier, Version 4.1: A Computer Program for Stochastic Frontier Production and Cost Function Estimation, CEPA Working Paper, No.7/96, Department of Econometrics, University of New England, Armidale, Australia.

Cornia, G. A. (1985). Farm Size, Land Yields and the Agricultural Production Function: An Analysis for Fifteen Developing Countries. World Development, 13(4), 513-534. https://doi.org/10.1016/0305-750X(85)90054-3

Furková, A., \& Surmanová, K. (2011). Stochastic Frontier Analysis of Regional Competitiveness, Quantitative Methods in Economics, 12(1), 67-76.

Govt. of West Bengal. (1990-91 to 2013-14). District Statistical Hand Books, Bureau of Applied Economics and Statistics, Government of West Bengal, Various issues.

Govt. of West Bengal. (1990-91 to 2013-14). Estimates of Area \& Production of Principal Crops in West Bengal, Evaluation Wing, Directorate of Agriculture, Government of West Bengal, Various issues.

Hasan, M. Z., Kamil, A. A., Mustafa, A., \& Baten, M. A. (2012). Stochastic Frontier Model Approach for Measuring Stock Market Efficiency with Different Distributions, PLOS/ ONE. Retrieved from https://doi.org/10.1371/journal.pone.0037047

India Population-2017. Population of West Bengal- 2017. Retrieved from http://indiapopulation2017.in/population-of-west-bengal2017.html

Joshi, P. K., Gulati, A., Birthal, P. S., \& Tewari, L. (2004). Agricultural Diversification in South Asia: Patterns, Determinants and Policy Implication, Economic \& Political Weekly, 39(24).

Kodde, D. A., \& Palm, F. C. W. (1986). Criteria for Jointly Testing Equality and Inequality Restrictions, Econometrica, 54(5), 1243-1248. https://doi.org/10.2307/1912331

Kompas, T., \& Che, N. (2006). Technology choice and efficiency on Australian dairy farms. Australian Journal of Agricultural and Resource Economics, 50(1), 65-83. https://doi.org/10.1111/j.1467-8489.2006.00314.x

Koopmans, T. C. (1951). An analysis of Production as Efficient Combination of Activities. In Activity Analysis of Production and Allocation, Koopmans, T.C., eds, Cowles Commission for Research in Economics, Monograph no. 13. New York

Kumbhakar, S. C., Ghosh, S., \& MacGuckin, J. T. (1991). A Generalized Production Frontier Approach for Estimating Determinants of Inefficiency in U.S Dairy Farms. Journal of Business and Economic Statistics, 9(3), 279-286. https://doi.org/10.1080/07350015.1991.10509853

Laha, A. (2013). Technical Efficiency in Agricultural Production and Access to Credit in West Bengal, India: A Stochastic Frontier Approach. International Journal of Food and Agricultural Economics, 1(2), 53-64.

Li, Z. Z., \& Li, D. G. (2011). The impact of agricultural extension on technical efficiency of agricultural production in China, IEEE $3^{\text {rd }}$ International Conference on Communication software and Networks, China. https://doi.org/10.1109/ICCSN.2011.6013869

Manjunatha, A. V., Anik, A. R., Speelman, S., \& Nuppenau, E. A. (2013). Impact of land fragmentation, farm size, land ownership and crop diversity on profit and efficiency of irrigated farms in India. Land Use Policy, 31, $397-405$. https://doi.org/10.1016/j.landusepol.2012.08.005

Mithiya, D., Mandal, K., \& Bandyopadhyay, S. (2018). Diversification towards horticulture as a source of income and employment in West Bengal, International Journal of Current Research, 10(7), 71996-72004.

Ogundari, K. (2013). Crop diversification and technical efficiency in food crop production: A study of peasant farmers in Nigeria. Int. J. Social Economics, 40, 267-287. https://doi.org/10.1108/03068291311291536

Pitt, M., \& Lee, L. (1981). The Measurement and Sources of Technical Efficiency in the Indonesian Weaving Industry. Journal of Development Economics, 9, 43-64. https://doi.org/10.1016/0304-3878(81)90004-3

Sahriman, S., Djuraidah, A., \& Wigena, A. H. (2014). Application of Principal Component Regression with Dummy Variable in Statistical Downscaling to Forecast Rainfall. Open Journal of Statistics, 4, 678-686. https://doi.org/10.4236/ojs.2014.49063

Van-Zyl, J., Binswanger, H., \& Thirtle, C. (1995). The Relationship between Farms Size and Efficiency in South African Agriculture, Washington D.C, Policy Research Working Paper, No1548, World Bank.

Yotopoulous, P. A., \& Lau, L. J. (1973). Test of relative economic efficiency: some further results. The American 
Economic Review, 63(1), 214- 225.

\begin{abstract}
${ }^{\mathrm{i}}$ Panel data contains more information than a single cross section, it therefore enables to relax some strong assumptions used in cross-sectional data and to obtain estimates of technical efficiency with more desirable statistical properties. The main diff erence between cross sectional and panel-data estimation techniques is that with cross-sectional data it is only possible to estimate the performance of each production farm (district) at a specific period in time, whereas with panel data, we are able to estimate the time pattern of performance for each production farm (district). One problem with cross sectional data in efficiency measurement is that technical inefficiency cannot be separated from farm specific eff ects that are not related to inefficiency (Battese and Coelli 1995). Panel data avoids this problem. While implementing inefficiency measurement using panel data, it is important to distinguish technical inefficiency from farm (district) and time specific eff ects. These eff ects are normally separate from exogenous technical progress. In a panel data context, it is possible to decompose the error into district specific eff ects, time specific eff ects, the white noise and technical inefficiency (Kumbhakar, 1991).
\end{abstract}

\title{
Annexure
}

Table 1. Rotated Component Matrix a of Determinant of Technical Efficiency of Agricultural Farm in West Bengal

\begin{tabular}{lrrr}
\hline & \multicolumn{3}{c}{ Component } \\
\hline & 1 & 2 & 3 \\
Size of Holding ( ha) & 0.649 & 0.552 & -0.429 \\
Labour Intensity (Lab / Ha) & 0.628 & -0.137 & 0.452 \\
\% of Small and Marginal Land Holder & -0.946 & -0.120 & -0.090 \\
Fertiliser Intensity (Kg./ Ha) & -0.080 & 0.818 & 0.006 \\
Education (\%) & 0.290 & 0.803 & 0.120 \\
Irrigation Intensity (\%) & 0.078 & 0.141 & 0.126 \\
Number of Market & -0.020 & 0.008 & 0.905 \\
Crop Diversification & -0.010 & 0.264 & 0.069 \\
\hline
\end{tabular}

Extraction Method: Principal Component Analysis.

Rotation Method: Varimax with Kaiser Normalization

a. Rotation converged in 6 iterations.

\section{Copyrights}

Copyright for this article is retained by the author(s), with first publication rights granted to the journal.

This is an open-access article distributed under the terms and conditions of the Creative Commons Attribution license which permits unrestricted use, distribution, and reproduction in any medium, provided the original work is properly cited. 